\title{
Distinctive Roles of Sirtuins on Diabetes, Protective or Detrimental?
}

OPEN ACCESS

Edited by:

Yang Yang,

Northwest University, China

Reviewed by:

Juei-Tang Cheng,

Chang Jung Christian University,

Taiwan

Ankush Sharma,

University of Oslo, Norway

Haitao Wang,

Southern Medical University, China

Chung Yeng Looi,

Taylor's University, Malaysia

*Correspondence:

Liang Feng

wenmoxiushi@163.com

Specialty section:

This article was submitted to

Cellular Endocrinology,

a section of the journal

Frontiers in Endocrinology

Received: 23 August 2018 Accepted: 15 November 2018

Published: 29 November 2018

Citation:

Song J, Yang B, Jia X, Li M, Tan W, Ma S, Shi $X$ and Feng L (2018)

Distinctive Roles of Sirtuins on

Diabetes, Protective or Detrimental?

Front. Endocrinol. 9:724.

doi: 10.3389/fendo.2018.00724

\author{
Jie Song ${ }^{1,2}$, Bing Yang ${ }^{1,3}$, Xiaobin Jia ${ }^{1}$, Mingyu $\mathrm{Li}^{3}$, Wei Tan ${ }^{2}$, Shitang $\mathrm{Ma}^{4}$, Xinhong Shi ${ }^{1}$ \\ and Liang Feng ${ }^{1 *}$
}

${ }^{1}$ School of Traditional Chinese Pharmacy, China Pharmaceutical University, Nanjing, China, ${ }^{2}$ Affiliated Hospital on Integration of Chinese and Western Medicine, Nanjing University of Chinese Medicine, Nanjing, China, ${ }^{3}$ Nanjing University of Chinese Medicine, Nanjing, China, ${ }^{4}$ Life and Health college, Anhui Science and Technology University, Fengyang, China

Dysregulation of metabolic pathways leads to type 2 diabetes, characteristic of high glucose concentration caused by insulin resistance. The histone deacetylases sirtuins exhibit remarkable enzymatic activities. Accumulating evidence indicates that sirtuins can be pharmacologically activated to ameliorate diabetes. Here, we evaluated different roles of sirtuins (SIRT1-SIRT7) in diabetes progression and described their involvement in metabolic pathways of skeletal muscle, adipose tissue and liver. The nuclear sirtuins, SIRT1, SIRT6, and SIRT7, regulate the activity of key transcription factors and cofactors in almost all tissues with the cellular responses to energy demands. The mitochondrial sirtuins, SIRT3, SIRT4, and SIRT5, regulate the activity of mitochondrial enzymes in response to fasting and calorie restriction. Moreover, genetic polymorphisms of SIRT1 and SIRT2 have been reported to associate with diabetes development. It's worth noting that SIRT1, SIRT2, SIRT3, and SIRT6 are positive regulators of insulin resistance in most cases. In the opposite, SIRT4 and SIRT7 inhibit insulin secretion and fatty acid oxidation. Identification of SIRT1 activators for diabetes has gained wide attention, such as metformin, resveratrol, and resveratrol derivatives. Randomized, prospective, and large-scale clinical trials are warrant to uncover the responsibilities of SIRTs modulators on diabetes progress.

\section{Keywords: SIRTs, diabetes, insulin resistance, glucose uptake, fatty acid oxidation}

\section{INTRODUCTION}

Sirtuins belong to class III histone deacylases, and in each deacylation cycle one molecule $\mathrm{NAD}^{+}$is consumed (1). SIRTs isoforms have been defined in mammals, such as SIRT1-7. Although they are equipped with a highly conserved structure of about 275 amino acids, just like the silent information regulator 2 in yeast (2), the $\mathrm{C}$-and $\mathrm{N}$-terminal extensions are distinctive, which are the predominant factor of sirtuins subcellular localization (3). SIRT1, SIRT6, and SIRT7 are principally found in the nucleus. SIRT2 is mainly located in the cytoplasm, and SIRT3-5 are located in the mitochondria (Figure 1). The catalytic core is made up of a small zinc-binding domain, a large Rossmann-fold domain, and a few flexible loops which bind these domains together. The large domain of most sirtuins resembles each other, characteristic of a $\beta$-sheet encircled by six $\alpha$-helices, excluding SIRT2, which has seven $\alpha$-helices (4). In the small domain, diversities are observed in the principal sequence. Firstly, the helix bundle is only absent in SIRT7 and SIRT6. Next, SIRT5 and SIRT4 have a loop and a short helix, yielding an insertion in the small domain. This feature 
might be essential for the mitochondrial localization (5). Lastly, SIRT1 has a 5-residue loop in this domain, neighboring to the zinc-binding cysteine. Those dissimilarities in the catalytic core might closely relate with their key properties.

SIRT1-3 and SIRT6 exhibit remarkable demyristoylase activity $(6,7)$. Except for functioning as an ADP-ribosyltransferase $(8,9)$, SIRT4 also possesses a lipoamidase effect (10). By targeting carbamoyl phosphate synthetase (CPS1), SIRT5 can remove malonyl or succinyl groups in a manner very similar to deacetylation $(11,12)$. SIRT6 deacetylates histone H3K9 \& H3K56, and mono-ADP-ribosyltransferate long-chain acyl and acetyl groups (13). SIRT7 is distributed in all organs and tissues (14) and activates RNA polymerase I transcription. Although several of its molecular substrate have been identified, including WSTF-ISWI chromatin remodeling complex (WICH), rDNA transcription factor UBF (the nucleolar upstream-binding factor) and RNA polI (15), SIRT7's catalytic activity remains elusive.

Diabetes is a global epidemic problem growing exponentially, posing a serious threat. Type 2 diabetes mellitus (T2DM) is a multifactorial metabolic and endocrine disorder for human beings, characteristic of abnormal glucose level in blood. T2DM individuals are estimated to be 642 million by 2,040 globally (16). T2DM is predominately attributed to insulin resistance and pancreatic $\beta$-cell dysfunction (17, 18). Insulin resistance, primarily in liver, muscle and adipose tissue as well, spoils glucose disposal, leading to $\beta$-cell insulin increase and hyperinsulinemia in a compensatory manner.

Blunted sirtuin activity has been reported to induce diabetes and metabolic syndrome, and aggravate high-fat diet (HFD) effects in mice. Exceptionally, SIRT4 prevents insulin secretion and stimulates T2DM. SIRT4 also negatively regulates fatty acid oxidation (FAO) in muscle and liver cells. A mutation in human SIRT1 caused a familial form of autoimmune diabetes (19-21). SIRT1 can interact with transcription factors and coactivators (RelA/p65, FOXO, and p53). T2DM group has lower SIRT1 mRNA levels compared with healthy group. There is a negative connection between fasting plasma glucose and SIRT1, as shown in the correlation analysis. The expression of SIRT1 in monocytes and granulocytes of T2DM might associate with glucose/lipid metabolism status (22). In both of the kidney and liver of diabetic rats, SIRT1 and SIRT2 gene expressions reduced considerably than blank control group (23). HFD triggers SIRT1 decrement in mice probably via proteolysis (19). SIRT1 expression is also reduced in obese humans $(24,25)$, and meanwhile diabetes is alleviated in SIRT1overexpressed mice (26-28). SIRT6 is important for sustaining pancreatic $\beta$-cell function in mice. SIRT6 knockout leads to severe hypoglycemia in mice. SIRT6 deficiency results in liver steatosis and accelerates insulin resistance and obesity induced by diet. Overnutrition and aging decreased SIRT6 level as well as irregular lipid and glucose metabolism (29). SIRT7 deficiency in mice induces multi-systemic mitochondrial dysfunction. To fully understand the part SIRTs play in diabetes and to reveal regulatory mechanisms regarding SIRTs is the principal purpose in the current review.

\section{SIRTS IN INSULIN RESISTANCE}

Pancreatic $\beta$ cells secret insulin after nutrient stimulation. In the fed state, glycolysis, glucose uptake, and glycogen formation will be promoted by insulin. The glucose homeostasis in adipose tissue and skeletal muscle can also be regulated by insulin (30). Insulin resistance will give rise to hyperuricemia, visceral adiposity, dyslipidemia, hypertension, and hyperglycemia. About $70 \%$ of glucose is disposed in muscle. Free fatty acids accumulation and inflammation in muscle triggeres abundant lipid deposition. Imbalanced muscle uptake promotes extra glucose to returns to the liver, which yields intense circulation of free fatty acids, finally leading to fat accumulation and insulin resistance.

As a major inhibitor of the insulin receptor, protein tyrosine phosphatase $1 \mathrm{~b}$ (PTP1B) can be inhibited by SIRT1, thus increasing insulin sensitivity (31-33). In insulin-resistant obese mice, PTP1B level was raised, associated with decreased SIRT1 expression in skeletal muscle. SIRT1 overexpression brought PTP1B expression to the baseline and abrogated the insulinstimulated signaling in skeletal muscle (Figure 2 and Table 1). In $\beta$-cells, SIRT1 overexpression boosted insulin secretion and improved glucose tolerance, contributing to glucose homeostasis (34). Uncoupling protein 2 (UCP2) disturbs the electrochemical proton gradient, leading to shrink in ATP production and insulin secretion impairment afterwards (35). SIRT1 overexpression suppressed UCP2, finally enlarging ATP levels and insulin secretion $(34,36)$. UCP2 expression in MIN6 $\beta$-cells was reduced by SIRT1, as demonstrated in microarray assays. SIRT1 RNAi decreased the secretion capability of $\beta$-cells, which was renovated by UCP2 RNAi (36). On the other side, oxidative stressinduced hyperglycemia and cytokine toxicity was repressed by SIRT1 via deacetylating forkhead box O1 (FOXO1) and the $\mathrm{NF}-\kappa \mathrm{B}$ subunit p65 on $\beta$-cells, respectively $(37,38)$. Multiple feedback loops are involved in SIRT signaling network. Via binding to SIRT1 promoter, p53 successfully inhibited SIRT1 transcription activity (39). FOXO3a can block the effect of p53, in consequence SIRT1 promoter will be relieved (39). Peroxisome Proliferator Activated Receptor Gamma (PPAR $\gamma$ ) is negatively associated with SIRT1 activity $(40,41)$, whereas PPAR $\alpha$ and PPAR $\beta$ function in the opposite way $(42,43)$. MiR-199a, MiR$34 \mathrm{a}$, posttranslational modification, such as phosphorylation, also affect SIRT1 activity or transcription (44-47). Taken together, SIRT1 positively regulated insulin sensitivity.

Recently, SIRT2 has been implicated in sustaining insulin sensitivity and glucose homeostasis (48). In insulin-resistant livers and hepatocytes, SIRT2 expression was lowered, accompanied with mitochondrial dysfunction, extracellular signal-regulated kinase (ERK) activation, and amplified production of reactive oxygen species (ROS). On the contrary, insulin sensitivity and mitochondrial dysfunction was improved, and ROS generation was lessened in SIRT2-overexpressed insulin-resistant hepatocytes (49). In human peripheral blood mononuclear cells (PBMCs), insulin resistance and obesity negatively related with SIRT2 (50). As Protein Kinase B (Akt) substrates, FOXO transcription factors are deacetylated by SIRT2 (51-54). However, the function of SIRT2 in insulin 


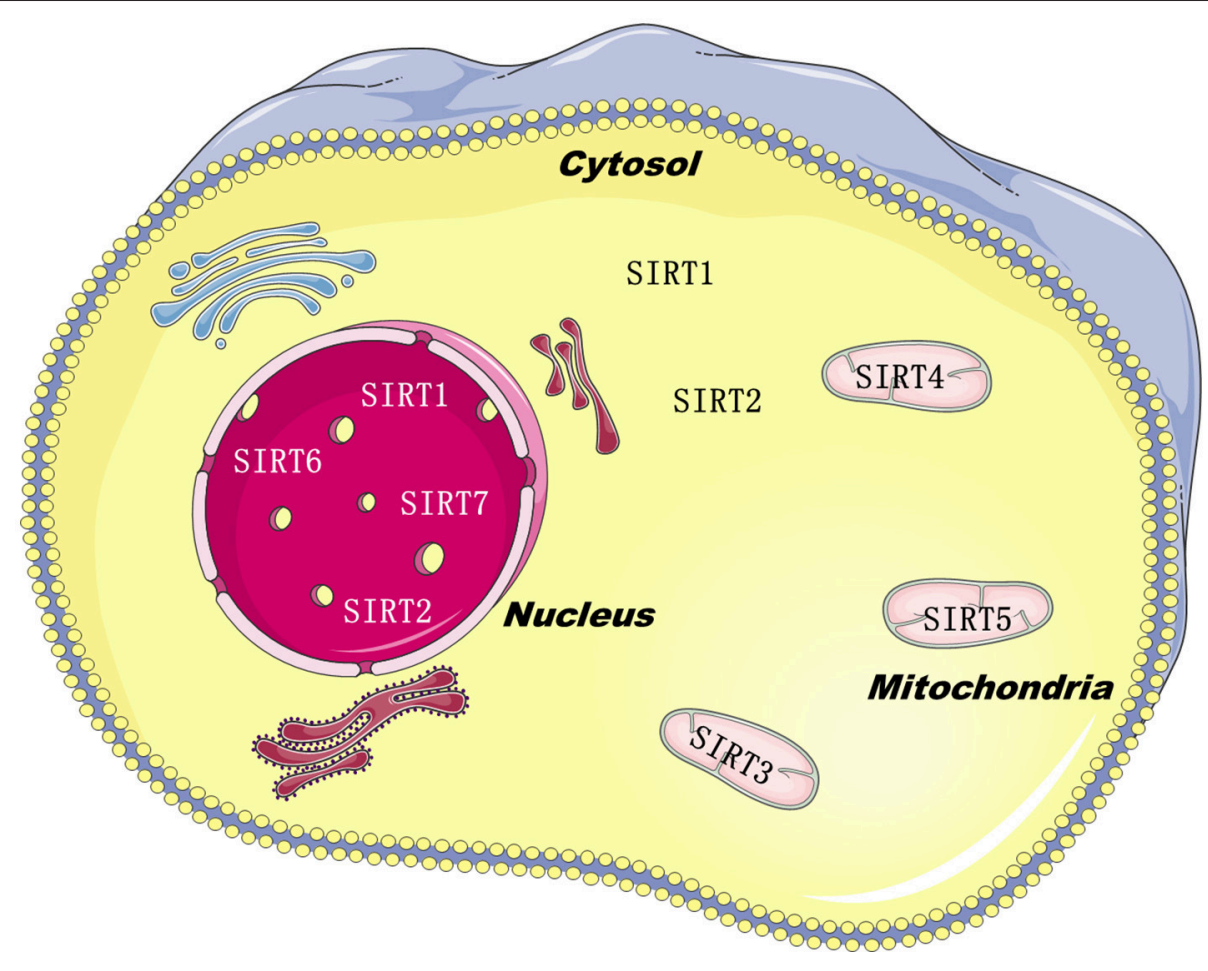

FIGURE 1 | The localization of SIRTs family in the cells.

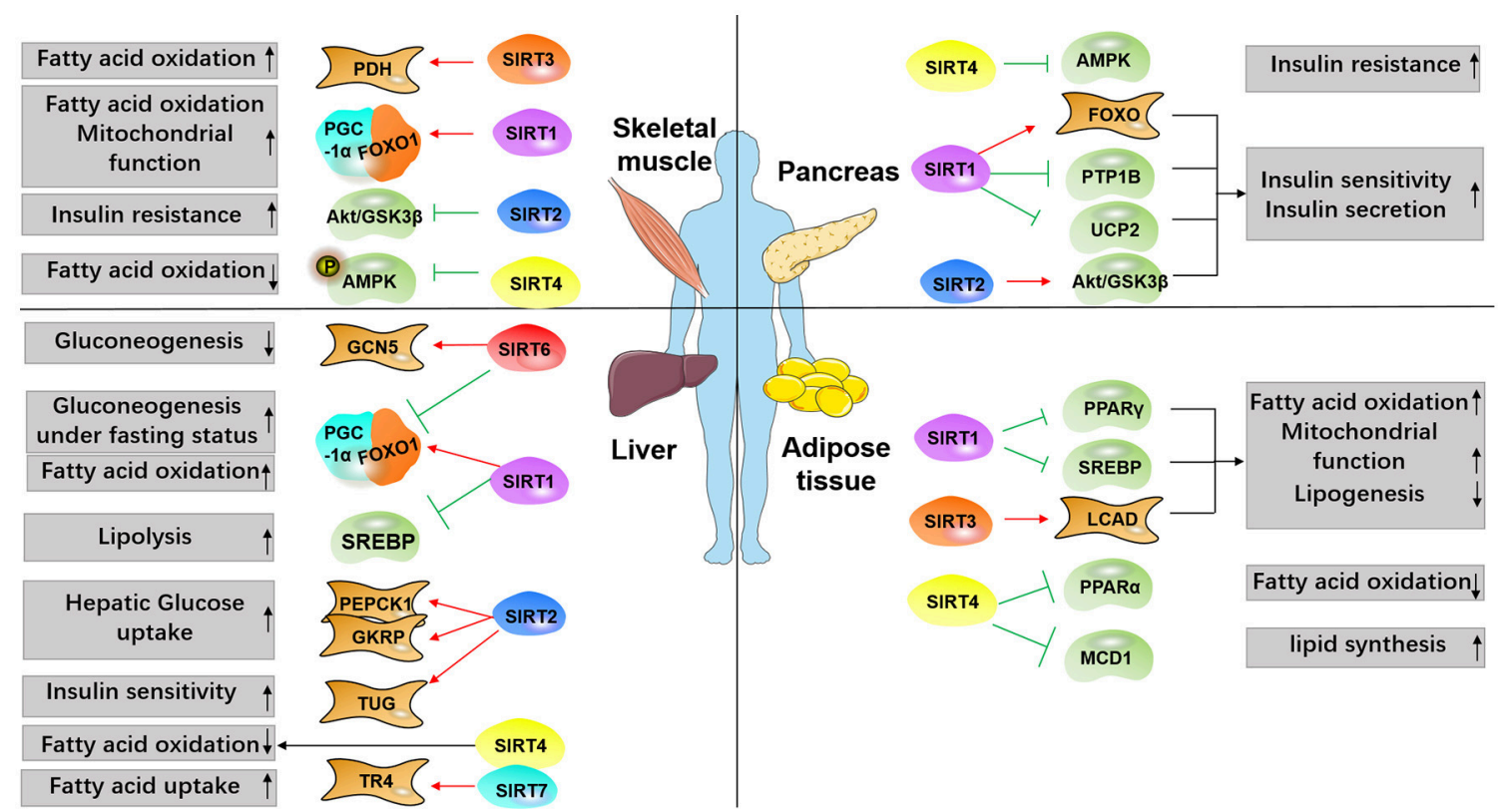

FIGURE 2 | Overview of SIRTs targets involved in diabetes. Major metabolic tissues, including liver, pancreas, adipose, and skeletal muscle are depicted to demonstrate SIRTs functions in the metabolic process modulating insulin resistance, glucose uptake, and lipid synthesis. Red arrows indicate promoting effect, and green arrows indicate inhibiting effect. 
TABLE 1 | Summary of sirtuin functions in diabetes development.

\begin{tabular}{|c|c|c|c|c|}
\hline Sirtuins & $\begin{array}{l}\text { Subcellular } \\
\text { localization }\end{array}$ & Enzyme actions & Substrates & Functions \\
\hline SIRT1 & $\begin{array}{l}\text { Nuclear } \\
\text { Cytoplasm }\end{array}$ & Deacetylase & $\begin{array}{l}\text { PTP1B, UCP2, PPAR } \alpha, \text { PPAR } \gamma, \\
\text { PPAR } \gamma 2, \text { p53, FOXO1, PGC-1 } \alpha, \\
\text { NF-кB, CRTC2, SREBP }\end{array}$ & $\begin{array}{l}\text { Adipogenesis } \downarrow \text { Lipogenesis } \downarrow \text { Lipolysis } \uparrow \text { FAO } \uparrow \\
\text { Glucose uptake } \uparrow \text { Mitochondrial biogenesis } \uparrow \\
\text { Insulin secretion } \uparrow \text { in the fed state } \\
\text { Hepatic gluconeogenesis } \uparrow \text { in fasted state } \\
\text { Preserve glucose homeostasis under fasted and fed } \\
\text { conditions }\end{array}$ \\
\hline SIRT2 & $\begin{array}{l}\text { Cytoplasm } \\
\text { (nuclear } \\
\text { during interphase } \\
\text { and mitosis) }\end{array}$ & $\begin{array}{l}\text { Deacetylase } \\
\text { ADP-ribosyltransferase } \\
\text { Demyristoylase }\end{array}$ & $\begin{array}{l}\text { ERK1/2, GSK3 } \beta, \text { p70S6 Akt, FOXO, } \\
\text { TUG, GKRP, PEPCK1, PGC- } 1 \alpha\end{array}$ & $\begin{array}{l}\text { Adipogenesis } \downarrow \text { Lipolysis } \uparrow \text { FAO } \uparrow \text { HGU } \uparrow \\
\text { Regulation of adipocyte differentiation } \\
\text { Insulin sensitivity } \uparrow \text { in insulin-resistant hepatocytes, } \\
\text { mitochondrial dysfunction } \downarrow \\
\text { Insulin sensitivity } \downarrow \text { in skeletal muscle cells } \\
\text { Skeletal muscle glucose uptake } \downarrow\end{array}$ \\
\hline SIRT3 & Mitochondrial & $\begin{array}{l}\text { Deacetylase } \\
\text { Decrotonylase }\end{array}$ & PGC-1 $\alpha$, AMPK, CREB, PDH, LCAD & $\begin{array}{l}\text { FAO } \uparrow \\
\text { Insulin resistance } \downarrow \text { in skeletal muscle } \\
\text { Regulate mitochondrial antioxidant defense enzymes, } \\
\text { ROS } \downarrow \\
\text { Urea cycle and ketogenesis in liver } \uparrow\end{array}$ \\
\hline SIRT4 & Mitochondrial & $\begin{array}{l}\text { ADP-ribosyltransferase } \\
\text { Deacetylase } \\
\text { Lipoamidase }\end{array}$ & $\begin{array}{l}\text { PGC-1 } \alpha, \text { AMPK, Adenine } \\
\text { translocator, IDE, Glutamate } \\
\text { dehydrogenase, MCD1 }\end{array}$ & $\begin{array}{l}\text { Lipogenesis } \uparrow F A O \downarrow \\
\text { Hepatic lipid accumulation } \uparrow \\
\text { Insulin secretion } \downarrow \\
\text { Mitochondrial biogenesis } \downarrow\end{array}$ \\
\hline SIRT5 & Mitochondrial & $\begin{array}{l}\text { Deacetylase } \\
\text { Desuccinylase } \\
\text { Deglutarylase } \\
\text { Demalonylase }\end{array}$ & IDH2, G6P, CPS1 & $\begin{array}{l}\text { Ammonia detoxification } \uparrow \\
\text { Regulates glucose oxidation, FAO, ROS } \\
\text { Cellular antioxidant defense } \uparrow\end{array}$ \\
\hline SIRT6 & $\begin{array}{l}\text { Nuclear, } \\
\text { associated to } \\
\text { chromatin }\end{array}$ & $\begin{array}{l}\text { Deacetylase } \\
\text { ADP-ribosyltransferase } \\
\text { Demyristoylase }\end{array}$ & $\begin{array}{l}\text { HIF-1 } 1 \alpha \text {, Akt, FOXO1, GCN5, IGF-1, } \\
\text { NF-кB, GLUT1, LDH, PGK1, PFK-1 }\end{array}$ & $\begin{array}{l}\text { Insulin resistance } \downarrow \text { Gluconeogenesis } \downarrow \\
\text { Mimics the effect of calorie restriction } \\
\text { Maintains glucose homeostasis and repress } \\
\text { mitochondrial respiration by acting as an HIF-1 } 1 \alpha \\
\text { corepressor }\end{array}$ \\
\hline SIRT7 & Nucleolar & Deacetylase & TR4/TAK1, Cd36, PPAR $\gamma$ & $\begin{array}{l}\text { Adipogenesis } \uparrow \text { Fatty acid uptake } \uparrow \\
\text { Hepatic lipid accumulation } \uparrow \\
\text { Triglyceride synthesis/storage } \uparrow \\
\text { Controversy of fatty liver development in SIRT7 knockout } \\
\text { mice }\end{array}$ \\
\hline
\end{tabular}

Green shade infers detrimental effect, while red shade infers protective effect. The symbol $\uparrow$ means increment, and $\downarrow$ means decrement.

signaling is still controversial. Under standard nutrient conditions, it has been suggested that Akt activation in insulinresponsive cells is mainly attributed to SIRT2, other than SIRT1 $(55,56)$. However, SIRT2 overexpression strengthened insulin-induced Akt/GSK3//p70S6 signaling in HeLa cells and 3T3-L1 preadipocytes (56). It's elusive whether the phenomenon was caused by alteration of Akt acetylation status. Further investigations are needed to explore whether Akt deacetylation mediated by SIRT2 disturbs both protein binding and downstream pathway. TUG (tether, containing a UBX domain, for GLUT4) plays a role in the exocytosis of glucose transporter type 4 (GLUT4) (57), and binds with SIRT2. SIRT2 regulated the acetylation of TUG in vitro and in vivo (58). Enhanced TUG acetylation was observed in the liver of SIRT2 knockout mice, alone with greater glucose uptake and more GLUT4 storage vesicles in response to insulin (58). Altogether, SIRT2 may exert distinctive and even opposing effect in response to insulin in different tissues.
However, SIRT4 has been reported to inhibit insulin secretion $(9,59,60)$. SIRT4 overexpression promotes lipogenesis and dyslipidimeia, and meanwhile diminishes FAO. All these will lead to insulin resistance (21). SIRT4 mono-ADPribosylates insulin degrading enzyme and ATP/ADP translocases in $\beta$ cells, leading to downregulation of insulin secretion induced by glucose (61). SIRT4 deletion declines ATP level and low ATP level will activate 5 'adenosine monophosphate-activated protein kinase (AMPK), PGC- $1 \alpha$ and its target genes, both of which are involved in mitochondrial biogenesis and FAO. Dysregulation of AMPK signaling leads to autophagy deactivation, oxidative stress, and inflammation which are implicated in pathogenesis of insulin resistance (62).

SIRT6 plays an essential role pancreatic $\beta$-cell function and survival in mice (63). SIRT6 protected against insulin resistance and obesity induced by HFD (64). Akt phosphorylation at Ser 473 and Thr 308 were negatively regulate by SIRT6 through interfering with insulin receptors, insulin receptor substrate and 
various upstream molecules (65). In SIRT6 deficiency mice, increased Akt phosphorylation and activated insulin signaling is observed, yielding more glucose uptake and even hypoglycemia. Additionally, glucose induced more cell apoptosis and impaired insulin secretion severely in MIN6 $\beta$-cells in SIRT6 ablation mice. Contrariwise, SIRT6 overexpression rescued $\beta$-cell apoptosis and dysfunction $(66,67)$.

Hence activating SIRT1, SIRT3, and SIRT6 would be a right option to struggle with $\mathrm{T} 2 \mathrm{DM}$ due to the repression on PTP1B and UCP2 and final increment in insulin secretion. But SIRT4 functions in a negative way in diabetes development.

\section{SIRTS IN GLUCOSE METABOLISM AND HOMEOSTASIS}

During energy restriction status, glucose will be provided by the liver to sustain normoglycemia, initially in the glycogenolysis manner and then changing to gluconeogenesis (68). In the fed condition, insulin is secreted to suppress gluconeogenic enzymes transcription including phosphoenolpyruvate carboxykinase (PEPCK1), fructose-1,6-bisphosphatase, and glucose-6-phosphatase (G6P). PGC-1 $\alpha$ and FOXO1 can upsurge gluconeogenic enzyme genes transcription $(69,70)$.

SIRT1 motivates hepatic gluconeogenesis in fasting status. In contrast, SIRT1 sensitizes insulin and lowers glucose under insulin-resistant condition (71). SIRT1 also deacetylates PGC$1 \alpha$, and subsequently improves gluconeogenic genes expression in the liver $(71,72)$, finally encouraging hepatic glucose output during fasting. SIRT2 deacetylates and stabilizes PEPCK1 under glucose deprivation conditions (73). Compromised hepatic glucose uptake (HGU) is the cause of postprandial hyperglycemia in T2DM patients (74). In diabetic mice fed with HFD, SIRT2 overexpression in liver rises HGU and alleviates glucose tolerance. In liver-specific SIRT2 knockdown mice, HGU was diminished and glucose tolerance was imbalanced. It has been reported that SIRT2 stimulates HGU probably via deacetylating K126 of glucokinase regulatory protein (GKRP) (74).

SIRT5 manipulates protein substrates which are involved in ROS management, FAO, ammonia detoxification, ketone body formation, and glucose oxidation by glutarylation, malonylation, and succinylation (75).

SIRT6 interferes with FOXO1, thus reducing gluconeogenic genes such as G6P and PEPCK (76). Hepatic gluconeogenesis was meaningfully upregulated in SIRT6 knockout mice, suggesting a compensatory reaction to hypoglycemia (77). General control non-repressed protein 5 (GCN5) acetylated PGC-1 $\alpha$ and diminished the transcriptional activity of PGC- $1 \alpha$ (72). SIRT6 could activate GCN5 (77). A hypoxia-inducible factor $1 \alpha$ (HIF$1 \alpha$ ) inhibitor would rescue the hypoglycemia phenotype in SIRT6 deficiency mice. Mice with SIRT6 knockout in brains exhibited lower levels of insulin-like growth factor 1 (IGF-1) and growth hormone than control mice, similar to the effect achieved in whole-body SIRT6 knockout mice (78), suggesting that the central nervous system is critical in glucose metabolism.

\section{SIRTS IN CALORIE RESTRICTION AND EXERCISE}

Calorie restriction (CR) has been reported to postpone the onset of diabetes. During the initial phase of CR, liver gluconeogenesis is activated by pancreatic a cells-secreted glucagon, during which the cyclic AMP response-elementbinding protein (CREB) and CREB-regulated transcription coactivator 2 (CRTC2) are involved. CR and exercise is beneficial for health and longevity, and genetic ablation of SIRT1, SIRT3, and SIRT6 would block the benefits provided by CR and exercise (79-83).

SIRT1 encourages FOXO1-tirggered gluconeogenesis in fasting (84). SIRT1 activators exert similar effects like CR (85, 86). However, this effect is reversed by CRTC2 deacetylation mediated by SIRT1 (84). SIRT1 then deacetylates and activates PGC- $1 \alpha$ to facilitate gluconeogenesis (71). CRTC2 supports gluconeogenesis in the initial stage of fasting. Hepatic SIRT1 reduced CRTC2 level via deacetylation and ubiquitination, at $18 \mathrm{~h}$ fasting. FOXO1 accounted for gluconeogenesis after $18 \mathrm{~h}$ of fasting (84). Mice exposed to long-term CR (18 months) displayed SIRT2 increment in kidney and white adipose tissue (WAT) but not in brain or liver (51). Likewise, short-term fasting $(24 \mathrm{~h})$ also enhances protein and mRNA expression of SIRT2 in WAT (53). SIRT6 also accounted for CR function. SIRT6 knockout eliminated CR-induced life extension. SIRT6 Overexpression mimics the effects of exercise and CR in mice, and extends lifespan and health span, including reduced glucose, insulin, adipokines, cholesterol, and body weight $(64,87,88)$. In addition, CR-stimulated SIRT6 repressed NF-кB pathway (89). SIRT1 also transcriptionally activated SIRT6, therefore sirtuins might work in a coordinated way to modulate each phase of calorie restriction (29).

\section{SIRTS IN MITOCHONDRIAL GLYCOLYSIS AND BIOGENESIS}

ATP is generated in animal cells by two principal processes, glycolysis and mitochondrial oxidative phosphorylation. T2DM, obesity, and many other aging-related disorders are characteristic of amplified oxidative damage. ROS is generally produced in mitochondria, as superoxide $\left(\mathrm{O}_{2}^{-}\right)$is a byproduct during electron transport system metabolism. In response to excess glucose, SIRTs will orchestrate the ratio of respiration and glycolysis, consuming energy through proton leak (90).

SIRT1 deacetylates PGC-1 $\alpha$, which is critical for mitochondrial function and gluconeogenesis. SIRT1 directly deacetylates and activates PGC- $1 \alpha$ while SIRT3 enhances PGC-1 $\alpha$ protein expression indirectly(91), through activating CREB and AMPK which accordingly increases downstream mitochondrial biogenesis targets (92-94). Significant mortality, defective thermogenesis, decreased hypoglycemia, and reduced FAO are obvious in SIRT3 knockout models (95). SIRT3 also deacetylates key genes in oxidative stress and mitochondrial antioxidant defense enzymes. The beneficial effects of SIRT3 on CR can chiefly be ascribed to inhibiting ROS (83). Actually, the 
alleviation in cellular oxidative stress that generates during CR is absent in SIRT3 knockout mice (82).

In contrast to SIRT3, SIRT4 inhibits mitochondrial biogenesis by suppressing PGC-1 $\alpha$ expression. AMPK and SIRT4 interplay to retrograde PGC- $1 \alpha$ signaling, suggesting that SIRT4 negatively manipulates mitochondrial biogenesis (96). SIRT5 has been reported to promote antioxidant defense and sustain NADPH homeostasis in cells by increasing G6P deglutarylation and isocitrate dehydrogenase 2 (IDH2) desuccinylation (97). Interestingly, SIRT6 interacts with HIF-1 $\alpha$ to co-repress mitochondrial respiration (98). SIRT6 deficiency promoted HIF$1 \alpha$ activity and glycolysis by enhancing phosphofructokinase 1 (PGK1), glucose-6-phosphate isomerase, phosphoglycerate kinase (PFK-1), lactate dehydrogenase (LDH), and GLUT1 $(98,99)$.

\section{SIRTS IN THE METABOLIC HOMEOSTASIS OF SKELETAL MUSCLE}

Skeletal muscle is a critical tissue to maintain energy homeostasis. Storage of lipid metabolites and fatty acids in muscle prevents glucose uptake, finally leading to T2DM $(100,101)$. Induction of fatty acid $\beta$-oxidation has emerged as a hopeful method to attenuate muscle insulin resistance in muscle.

In skeletal muscle, SIRT1 expression is triggered by fasting. SIRT1 in turn deacetylates both FOXO1 and PGC-1 $\alpha$ and facilitates fatty acid $\beta$-oxidation (91). Likewise, FAO and mitochondrial biogenesis genes are upregulated owning to SIRT1 activators SRT1720 treatment via deacetylating PGC-1 $\alpha$ (27, 102). Moreover, SIRT1 plays a role in mitochondrial biogenesis induced by adiponectin in skeletal muscle (103).

SIRT2 negatively regulates insulin resistance and glucose uptake in C2C12 muscle cells. Akt/GSK3 $\beta$ signaling and glucose uptake which are driven by insulin was enlarged by inhibition of SIRT2 under insulin-resistance conditions (104). SIRT2 knockdown under insulin-resistant status enhanced insulin sensitivity in skeletal muscle cells. Nevertheless, blunt of SIRT3 and SIRT1 in C2C12 cells impairs insulin pathway and stimulates insulin resistance. Despite the fact that SIRTs possess a conserved catalytic domain, they exert a differential regulating effect on insulin resistance. SIRT3 Knockdown in muscle cells impairs insulin action and metabolic flexibility $(105,106)$, and muscle ability to adjust to fuel oxidation (107). SIRT3 deletion amplified acetylation of pyruvate hydrogenase (PDH), yielding declining $\mathrm{PDH}$ activity, and subsequent less glucose oxidation. All these gave rise to a switch to FAO, even with glucose available (106, 108).

SIRT4 negatively regulates mitochondrial biogenesis and FAO in muscles. SIRT4 regulates insulin secretion by modulating glutamate dehydrogenase. As expected, fat acid oxidative capability and mitochondrial metabolism enzymes in muscle and hepatocytes was upregulated in response to SIRT4 knockdown. In primary SIRT4 knockdown myotubes, phosphorylation of AMPK was activated, accompanied with intense cellular respiration and FAO. Moreover, protein and mRNA levels of SIRT1 were enhanced both in vitro and in vivo, largely attributed to the reduced SIRT4 levels (109).

\section{SIRTs IN FATTY ACID OXIDATION}

The development of T2DM and its complications is associated with lipid metabolism disorder. Inadequate $\mathrm{FAO}$ gives rise to the initiation of insulin resistance and lipid accumulation (110, 111).

SIRT1 fosters fat metabolism in liver cells, as demonstrated by the formation of fatty livers in mice with SIRT1 deletion in the liver $(112,113)$. SIRT1 knockout mice hardly suppressed lipogenic genes or increased FAO genes in the background of fasting (112). In normal hepatocytes, SIRT1 interacts with the PPAR $\alpha$ response element where it deacetylates PGC- $1 \alpha$ and increases PPAR $\alpha$ expression, thus stimulating FAO (113, 114). Furthermore, once the fat anabolism-inducing factor PPAR $\gamma$ was deacetylated by SIRT1, the sterol regulatory element binding proteins (SREBPs) will be deactivated and become more susceptible to degradation (115), achieving more lipolysis. Deacetylation of PGC- $1 \alpha$ and expression of $\beta$-oxidation genes was accordingly diminished due to SIRT2 function impairment (116).

SIRT3 plays an essential role in FAO in the mitochondria. Upon CR or fasting, SIRT3 is activated in mitochondria to stimulate FAO through inducing the deacetylation of long-chainspecific acyl coenzyme A dehydrogenase (LCAD) $(95,117)$. SIRT3 stimulates ketogenesis and urea cycle as well $(118,119)$. A chronic HFD reduced SIRT3 levels in mice, associated with LCAD function impairment and mitochondrial hyperacetylation (120).

SIRT4's effect is remarkably different from SIRT3 and SIRT1. Ablation of SIRT4 avoids steatosis during HFD (109). In addition, SIRT4 suppresses PPAR $\alpha$ to prevent FAO, in the meantime SIRT4 inhibits malonyl CoA decarboxylase 1 (MCD1) to facilitate the synthesis of lipid (29). SIRT4 interferes with SIRT1-PPAR $\alpha$ complex, therefore the activation effect of SIRT1 on PPAR $\alpha$ and the inhibiting effect on FAO was abrogated.

Analogous to SIRT4, SIRT7 knockout in liver resulted in blunted triglyceride accumulation. Hepatic SIRT7 facilitated triglyceride storage/synthesis and fatty acid uptake by activating TR4/TAK1, a nuclear receptor participating in lipid metabolism. Moreover, the ubiquitin-proteasome pathway is also involved in the regulating effect of hepatic SIRT7 on lipid metabolism (121). SIRT7 also hinders TR4 degradation. TR4 involves in lipid balance by modulating monoacylglycerol O-acyltransferase 1, Cidec, cell death-inducing DFFA-like effector a (Cidea), and Cd36. SIRT7 has been reported to upsurge hepatic lipid accumulation owning to increasing Cd36 expression (121, 122). Yoshizawa et al. (121) observed that HFD failed to stimulate glucose intolerance, obesity, or fatty liver in SIRT7 knockout mice. The conclusion is controversial to the result that SIRT7 knockout promoted fatty liver development (123, 124). Compared with SIRT1, SIRT7 displays distinctive effect on maintaining liver lipid homeostasisa. Lipid storage is raised by SIRT7 by suppressing PPAR $\alpha$, like SIRT4 (125). 


\section{SIRTS IN THE METABOLIC HOMEOSTASIS OF ADIPOCYTE}

Regarded as a storage compartment for fatty lipids, adipose tissue also serves as an important modulator for energy homeostasis, vascular remodeling endocrine functions, insulin sensitivity, and innate immune response (126). Adipokines, such as leptin and adiponectin, are systemically regulated by white adipose tissue (WAT). There is convincing evidence supporting that adiponectin derived from adipocyte plays an essential part in insulin resistance $(127,128)$. Moreover, adiponectin sustains glucose homeostasis and protects against diabetes and obesity.

Numerous SIRT1 benefits take place in WAT (129). SIRT1 inhibits lipogenesis and stimulates fat mobilization in adipocytes from WAT, via suppressing $\operatorname{PPAR} \gamma$. Eventually, peripheral utilization of the fat storages is raised (113). White fat can be switched to metabolically active brown fat due to SIRT1 deacetylation on PPAR $\gamma$ (130). Conversely, SIRT1 can be cleaved in WAT by caspase I and inflammasome which is activated by HFD (19).

SIRT1 knockdown reduced WAT mass in rats. The mRNA contents of PPAR $\gamma 2$ and PPAR $\gamma$, both of which were adipogenic genes, are abridged in adipose, driving adipocyte differentiation and adipose loss. Adipocytes-specific SIRT1 knockdown led to lower plasma concentrations of adiponectin and leptin. In adipose of obese individuals, mRNA levels of SIRT1 were lower in than those of control group. In the opposite, obese patients have higher SIRT7 expressions in adipose. SIRT7 and SIRT1 promoters' methylation status are not closely associated with the upregulation or downregulation of their mRNA levels induced by obesity. In visceral adipose tissue (VAT) of obese patients, the content of miR-181a-3p and miR-34a-5p negatively associated with SIRT1 levels. In contrary, the expression of miR-125b-5p and miR-125a-5p negatively correlated with SIRT7 in VAT of slim subjects (131). Furthermore, MiR-93 impedes the metabolic target SIRT7 (132).

SIRT7 has been identified as a chief driver of adipogenesis by inducing differentiation and maturation of early adipocyte precursors. PPAR $\gamma$ is adipogenic and its expression is reduced in the WAT of mice with SIRT7 deletion (132), designating that SIRT7 stimulates adipogenesis. SIRT7 can remove long-chain fatty acyl groups more efficiently than removing acetyl groups $(133,134)$.

Inhibited SIRT2 expression and amplified HIF-1 $\alpha$ expression are observed in VAT from obese individuals. HIF-1 $\alpha$ hinders adipocyte-mediated fatty acid catabolism by blocking SIRT2PGC- $1 \alpha$ pathway, thereby favoring the progression of obesity (116). Diet-induced obesity was strengthened in SIRT6 knockout mice, principally attributed to hypertrophy of adipocyte other than differentiation of abnormal adipocyte (135).

\section{SIRTS IN NEURONS UNDER DIABETIC CONDITIONS}

In the anorexigenic proopiomelanocortin (POMC) neurons, SIRT1 is critical in preserving normal energy expenditure.
POMC neurons-specific SIRT1 knockout mice are vulnerable to diet-induced obesity (136). SIRT1 is also defensive against diabetes and obesity in the steroidogenic factor 1 neurons (137). Additionally, the peptide release of orexigenic agouti is suppressed by SIRT1 via interacting with FOXO1 $(138,139)$. Nevertheless, SIRT1 ablation in neurons was related with insulin secretion in hypothalamic neurons (140).

SIRT2, PGC-1 $\alpha$, and P-AMPK declined dramatically in diabetic cortex. AMPK/SIRT/PGC-1 $\alpha$ pathway, which mediates antioxidant abilities and mitochondrial biogenesis, is involved in cortex neurodegeneration progression under diabetic conditions (141). SIRT6 and SIRT2 expression were meaningfully reduced in the neural stem or embryo cells from pre-gestational maternal diabetes. Superoxide dismutase 1 (SOD1) mimetic and overexpression rescued the decrement of SIRT6 and SIRT2 in the diabetic embryopathy mouse model. Histone acetylation caused by Sirtuin decrement might participates in neural tube defects induced by diabetes.

\section{SIRTS POLYMORPHISMS IN DIABETES}

While abundant data point to the essential role of SIRTs activities, there are genetic polymorphisms of SIRT1 and SIRT2 concerning diabetes. rs10509291 and rs7896005 in SIRT1 genes are associated with T2DM development as well as reduced acute insulin response (142). In a report about Japanese patients with T2DM, four single nucleotide polymorphisms (SNPs) in SIRT1 that were positively correlated with diabetic nephropathy, and a haplotype containing the SNPs within SIRT1 locus had a stronger association (143). Moreover, SIRT1 mutation has been reported to link with autoimmune diabetes. Type 1 diabetes mellitus (T1DM) is an autoimmune disease characteristic of autoimmune-mediated $\beta$ cell destruction. Lately, exome, and direct sequencing recognized a T-to- $\mathrm{C}$ exchange in exon 1 of SIRT1 in a patient diagnosed with T1DM, corresponding to a leucine-to-proline mutation at residue 107. It is speculated that the SIRT1 L107P mutation, located within the N-terminal protein-binding domain, could also disturb the oligomerization and activity (20). Furthermore, the prenatally famine-exposed kids, who have minor alleles of SIRT1 gene (GA and AA of rs1467568 and AG and GG of rs7895833), have a lower risk for T2DM in adult life (144). DNA sequence variants (DSVs), including g.38900237G > A, g.38900359C > T, g.38900561C > T, and g.38900912G > T, might upsurge SIRT2 gene promoter activity and SIRT2 levels, contributing to T2DM as a risk factor (50).

\section{CLINICAL TRIALS OF SIRTS ACTIVATORS IN DIABETES: CURRENT EVIDENCE}

As mentioned above, SIRTs activators exert positive effects in neurodegenerative, and metabolism diseases. Identification of SIRT1 activators for T2DM treatment has become immediate areas of research focus, such as metformin, resveratrol, resveratrol derivatives (Resveratrol aliphatic acids, acetylated

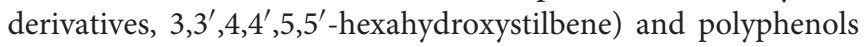


(quercetin, piceatannol, fisetin, pinosylvin, and butein) (145). Metformin is the recommended first-line oral glucose-lowering drug initiated to control hyperglycemia in T2DM, a synthetic dimethyl biguanid (146). SIRT1 level rises after metformin treatment. SIRT1 is obviously entangled into the mechanism of metformin action (147). In the largest Randomized Controlled Trial inspecting metformin for diabetes prevention $(148,149)$, 1073 subjects from 27 USA medical centers took metformin (850 mg twice every day) or placebo $(n=1082)$. As compared with placebo, diabetes occurrence was considerably decreased by $31 \%(95 \% C I=17 \%, 43 \%)$ in the metformin group after almost 3 years follow-up.

When it comes to another potent SIRT activator resveratrol, SIRTris Pharmaceuticals had launched an oral resveratrol formulation (SRT501), which has entered Phase III clinical trials for T2DM therapy (150). Effects of trans-resveratrol extract from Polygonum in patients with type 2 diabetes has completed Phase I clinical trials, with trial number NCT01677611 (151). In a dose-escalation Phase I trial, resveratrol clearance (5 $\mathrm{g}$ in a single dose) was rapid, and urine excretion reached $77 \%$ within $4 \mathrm{~h}$, signifying that derivatives structure optimization with longer half-life is in great need (152). Moreover, derivatives SRT-2183, SRT-1720, and SRT-1460 are also discovered. But SRT-1720 was terminated owing to limited effect. SRT-2104 was more potent and the Phase II clinical trials has completed successfully (153). The pharmacokinetics and safety study of SRT2379 evaluated in healthy male volunteers has finished the Phase I clinical trials (154).

\section{CONCLUSION}

SIRTs play a noticeable role in modulating insulin resistance and glucose uptake in adipose tissue, liver, and muscle. SIRT1, SIRT2, SIRT3, and SIRT6 has been implicated to positively sustain insulin sensitivity and glucose homeostasis, rendering them attractive potential drug targets. While SIRT4 and SIRT7 negatively regulate insulin secretion and FAO.

Specifically, SIRT1 enhances fat catabolism in adipose tissue, skeletal muscle and liver by modifying the activity of PPAR $\alpha$, $\operatorname{PPAR} \gamma$, and PGC-1 $\alpha$. Apart from inducing fat catabolism, SIRT1 also promotes FAO, mitochondrial oxidative capacity and energy expenditure in fat tissue and skeletal muscle, not only through direct activation of PPAR $\alpha$, but also through secondary activation of AMPK and PPAR $\alpha$ by SIRT1-mediated adiponectin synthesis. SIRT1 prevents lipogenesis and motivates free fatty acid release by inhibiting SREBP and PPAR $\gamma$. SIRT1 exhibits conflicting effects on maintaining glucose homeostasis under fed and fasted conditions. In fed condition, SIRT1 reinforces pancreatic insulin secretion. In fasted status, SIRT1 promotes hepatic gluconeogenesis by deacetylating FOXO1 and PGC- $1 \alpha$. SIRT1 exerts insulin-sensitizing effect by inhibiting PTP1B and UCP2 expression and regulating adiponectin synthesis. SIRT2 increases insulin sensitivity in insulin-resistant hepatocytes, while decreases insulin sensitivity in skeletal muscle cells. Nevertheless, there is very limited literature on SIRT5 enzyme activity until the recent finding as it can remove succinyl or malonyl groups, and this action resembles deacetylation. SIRT5 is broadly expressed, but SIRT5-deficient mice are healthy, fertile, and without major clinical phenotype (155), inferring that SIRT5 is not indispensable for metabolic homeostasis at least under basal conditions. SIRT6 supports pancreatic $\beta$-cell function and sustains glucose homeostasis by acting as a HIF$1 \alpha$ corepressor. Conversely, SIRT4 and SIRT7 exhibited negative effect on diabetes therapy, such as aggravating lipogenesis, and inhibiting insulin secretion.

The majority of sirtuins isoforms are protective on diabetes and a minority appears to be detrimental, but the antagonism effect on the whole body remains elusive. Although several metabolic pathways and targets have been proposed to mediate SIRTs function on T2DM, some outstanding questions need to be resolved. Moreover, do these SIRTs act independently or synergistically on diabetes? How do they communicate for cooperative actions in cells? SIRTs are regulated by proteinprotein interactions and microRNAs at the level of translation and transcription (156), however, little is known about the epigenetic mechanisms modifying sirtuins. In some cases, sirtuins isoforms regulate certain essential enzymes in an opposite direction. For instance, $\mathrm{PDH}$ can be activated through deacetylation by SIRT3 (106), while both delipoamidating by SIRT4 or desuccinylating by SIRT5 inhibited PDH activity $(157,158)$, and the question that which effect will win out is quite a puzzle. Furthermore, when SIRTs display both ADPribosyltransferase and deacetylase activity, the circumstances that decide the predominant activity need to be determined.

A plenty of clinical trials has been carried out, including resveratrol, metformin, and other SIRT activators. It is possible that in the foreseeable future one or more SIRT activators will be approved for diabetes therapy. As a well-known pharmaceutical preparation, the widespread usage of metformin facilitates the recruit of a large randomized controlled trial. Metformin has been regarded as the most promising candidate. But it's a little harder to explore the natural compounds in a large scale, such as curcumin, berberine, and genistein. It is attributed to the complexity in reducing batches variability of supplements and the difficulty in evaluating dietary intake in observational studies (159-161). Long-term, outcomes-based placebo-controlled rigorous clinical trials would be crucial to confirm the function of SIRT activators on diabetes.

\section{AUTHOR CONTRIBUTIONS}

JS and LF drafted the manuscript. All authors contributed in the discussion section, and approved it for publication.

\section{ACKNOWLEDGMENTS}

We acknowledge the financial support from the National Natural Science Foundation Committee of China (No. 81603336, $81703775,81873055)$, Jiangsu province high-level health personnel Six-One Project (LGY2017085), Jiangsu Province Youth Medical Key Talent Project (QNRC2016634), Innovative Research Team of Health Development Project with Science and 
Education in Jiangsu Province (CXTDB2017003), Program for Innovative Research Team of Six Talent Peaks Project in Jiangsu Province (SWYY-CXTD-004). The Public Welfare Technology
Application Research Linkage Project of Anhui Province (grant No. 1704f0704062). TCM for Public Interest Research from Ministry of Finance of China (No. 201507004).

\section{REFERENCES}

1. Imai S, Armstrong CM, Kaeberlein M, Guarente L. Transcriptional silencing and longevity protein Sir2 is an NAD-dependent histone deacetylase. Nature (2000) 403:795-800. doi: 10.1038/35001622

2. Chang HC, Guarente L. SIRT1 and other sirtuins in metabolism. Trends Endocrinol Metab. (2014) 25:138-45. doi: 10.1016/j.tem.2013.12.001

3. Haigis MC, Sinclair DA. Mammalian sirtuins: biological insights and disease relevance. Annu Rev Pathol. (2010) 5:253-95. doi: 10.1146/annurev.pathol.4.110807.092250

4. Parenti MD, Bruzzone S, Nencioni A, Del Rio A. Selectivity hotspots of sirtuin catalytic cores. Mol Biosyst. (2015) 11:2263-72. doi: $10.1039 / \mathrm{c} 5 \mathrm{mb} 00205 \mathrm{~b}$

5. Schuetz A, Min J, Antoshenko T, Wang CL, Allali-Hassani A, Dong A, et al. Structural basis of inhibition of the human NAD+-dependent deacetylase SIRT5 by suramin. Structure (2007) 15:377-89. doi: 10.1016/j.str.2007.02.002

6. Houtkooper RH, Pirinen E, Auwerx J. Sirtuins as regulators of metabolism and healthspan. Nat Rev Mol Cell Biol. (2012) 13:225-238. doi: $10.1038 / \mathrm{nrm} 3293$

7. Rauh D, Fischer F, Gertz M, Lakshminarasimhan M, Bergbrede T, Aladini F, et al. An acetylome peptide microarray reveals specificities and deacetylation substrates for all human sirtuin isoforms. Nat Commun. (2013) 4:2327. doi: $10.1038 /$ ncomms 3327

8. Teng YB, Jing H, Aramsangtienchai P, He B, Khan S, Hu J, et al. Efficient demyristoylase activity of SIRT2 revealed by kinetic and structural studies. Sci Rep. (2015) 5:8529. doi: 10.1038/srep08529

9. Haigis MC, Mostoslavsky R, Haigis KM, Fahie K, Christodoulou DC, Murphy AJ, et al. SIRT4 inhibits glutamate dehydrogenase and opposes the effects of calorie restriction in pancreatic beta cells. Cell (2006) 126:941-54. doi: 10.1016/j.cell.2006.06.057

10. Osborne B, Bentley NL, Montgomery MK, Turner N. The role of mitochondrial sirtuins in health and disease. Free Radic Biol Med. (2016) 100:164-174. doi: 10.1016/j.freeradbiomed.2016.04.197

11. Du J, Zhou Y, Su X, Yu JJ, Khan S, Jiang H, et al. Sirt5 is a NAD-dependent protein lysine demalonylase and desuccinylase. Science (2011) 334:806-9. doi: $10.1126 /$ science. 1207861

12. Nakagawa T, Lomb DJ, Haigis MC, Guarente L. SIRT5 deacetylates carbamoyl phosphate synthetase 1 and regulates the urea cycle. Cell (2009) 137:560-70. doi: 10.1016/j.cell.2009.02.026

13. Kuang J, Chen L, Tang Q, Zhang J, Li Y, He J. The role of Sirt6 in obesity and diabetes. Front Physiol. (2018) 9:135. doi: 10.3389/fphys.2018.00135

14. Ford E, Voit R, Liszt G, Magin C, Grummt I, Guarente L. Mammalian Sir2 homolog SIRT7 is an activator of RNA polymerase I transcription. Genes Dev. (2006) 20:1075-80. doi: 10.1101/gad.1399706

15. Tsai YC, Greco TM, Boonmee A, Miteva Y, Cristea IM. Functional proteomics establishes the interaction of SIRT7 with chromatin remodeling complexes and expands its role in regulation of RNA polymerase I transcription. Mol Cell Proteomics (2012) 11:60-76. doi: 10.1074/mcp.A111.015156

16. Zhou Z, Sun B, Li X, Zhu C. DNA methylation landscapes in the pathogenesis of type 2 diabetes mellitus. Nutr Metab. (2018) 15:47. doi: 10.1186/s12986-018-0283-x

17. Freeman AM, Pennings N. Insulin resistance. In: Treasure Island. Lumberton, NC: StatPearls (2018), p. 34.

18. Kahn SE, Cooper ME, Del Prato S. Pathophysiology and treatment of type 2 diabetes: perspectives on the past, present, and future. Lancet (2014) 383:1068-83. doi: 10.1016/S0140-6736(13)62154-6

19. Chalkiadaki A, Guarente L. High-fat diet triggers inflammation-induced cleavage of SIRT1 in adipose tissue to promote metabolic dysfunction. Cell Metab. (2012) 16:180-8. doi: 10.1016/j.cmet.2012.07.003

20. Biason-Lauber A, Boni-Schnetzler M, Hubbard BP, Bouzakri K, Brunner A, Cavelti-Weder C, et al. Identification of a SIRT1 mutation in a family with type 1 diabetes. Cell Metab. (2013) 17:448-455. doi: 10.1016/j.cmet.2013.02.001

21. Choubey SK, Prabhu D, Nachiappan M, Biswal J, Jeyakanthan J. Molecular modeling, dynamics studies and density functional theory approaches to identify potential inhibitors of SIRT4 protein from Homo sapiens: a novel target for the treatment of type 2 diabetes. J Biomol Struct Dyn. (2017) 35:3316-3329. doi: 10.1080/07391102.2016.1254117

22. Song R, Xu W, Chen Y, Li Z, Zeng Y, Fu Y. The expression of Sirtuins 1 and 4 in peripheral blood leukocytes from patients with type 2 diabetes. Eur J Histochem. (2011) 55:e10. doi: 10.4081/ejh.2011.e10

23. Arab Sadeghabadi Z, Ziamajidi N, Abbasalipourkabir R, Mohseni R. Garlic (Allium sativum) increases SIRT1 and SIRT2 gene expressions in the kidney and liver tissues of STZ- and STZ+niacinamide-induced diabetic rats. J Basic Clin Physiol Pharmacol. (2018) 29:463-7. doi: 10.1515/jbcpp-2017-0079

24. Pedersen SB, Olholm J, Paulsen SK, Bennetzen MF, Richelsen B. Low Sirt1 expression, which is upregulated by fasting, in human adipose tissue from obese women. Int J Obes. (2008) 32:1250-5. doi: 10.1038/ijo.2008.78

25. Costa Cdos S, Hammes TO, Rohden F, Margis R, Bortolotto JW, Padoin AV, et al. SIRT1 transcription is decreased in visceral adipose tissue of morbidly obese patients with severe hepatic steatosis. Obes Surg. (2010) 20:633-9. doi: 10.1007/s11695-009-0052-z

26. Baur JA, Pearson KJ, Price NL, Jamieson HA, Lerin C, Kalra A, et al. Resveratrol improves health and survival of mice on a high-calorie diet. Nature (2006) 444:337-42. doi: 10.1038/nature05354

27. Lagouge M, Argmann C, Gerhart-Hines Z, Meziane H, Lerin C, Daussin $\mathrm{F}$, et al. Resveratrol improves mitochondrial function and protects against metabolic disease by activating SIRT1 and PGC-1alpha. Cell (2006) 127:1109-22. doi: 10.1016/j.cell.2006.11.013

28. Bordone L, Cohen D, Robinson A, Motta MC, van Veen E, Czopik A, et al. SIRT1 transgenic mice show phenotypes resembling calorie restriction. Aging Cell (2007) 6:759-67. doi: 10.1111/j.1474-9726.2007.00335.x

29. Kim HS, Xiao C, Wang RH, Lahusen T, Xu X, Vassilopoulos A, et al. Hepaticspecific disruption of SIRT6 in mice results in fatty liver formation due to enhanced glycolysis and triglyceride synthesis. Cell Metab. (2010) 12:224-36. doi: 10.1016/j.cmet.2010.06.009

30. Saltiel AR, Kahn CR. Insulin signalling and the regulation of glucose and lipid metabolism. Nature (2001) 414:799-806. doi: 10.1038/414799a

31. Jukarainen S, Heinonen S, Ramo JT, Rinnankoski-Tuikka R, Rappou E, Tummers M, et al. Obesity is associated with low NAD(+)/SIRT pathway expression in adipose tissue of BMI-discordant monozygotic twins. J Clin Endocrinol Metab. (2016) 101:275-83. doi: 10.1210/jc.2015-3095

32. Sun C, Zhang F, Ge X, Yan T, Chen X, Shi X, et al. SIRT1 improves insulin sensitivity under insulin-resistant conditions by repressing PTP1B. Cell Metab. (2007) 6:307-19. doi: 10.1016/j.cmet.2007.08.014

33. Elchebly M, Payette P, Michaliszyn E, Cromlish W, Collins S, Loy AL, et al. Increased insulin sensitivity and obesity resistance in mice lacking the protein tyrosine phosphatase-1B gene. Science (1999) 283:1544-8.

34. Moynihan KA, Grimm AA, Plueger MM, Bernal-Mizrachi E, Ford E, CrasMeneur C, et al. Increased dosage of mammalian Sir2 in pancreatic beta cells enhances glucose-stimulated insulin secretion in mice. Cell Metab. (2005) 2:105-17. doi: 10.1016/j.cmet.2005.07.001

35. Zhang CY, Baffy G, Perret P, Krauss S, Peroni O, Grujic D, et al. Uncoupling protein-2 negatively regulates insulin secretion and is a major link between obesity, beta cell dysfunction, and type 2 diabetes. Cell (2001) 105:745-55. doi: 10.1016/S0092-8674(01)00378-6

36. Bordone L, Motta MC, Picard F, Robinson A, Jhala US, Apfeld J, et al. Sirt1 regulates insulin secretion by repressing UCP2 in pancreatic beta cells. PLoS Biol. (2006) 4:e31. doi: 10.1371/journal.pbio.0040031 
37. Kitamura YI, Kitamura T, Kruse JP, Raum JC, Stein R, Gu W, et al. FoxO1 protects against pancreatic beta cell failure through NeuroD and MafA induction. Cell Metab. (2005) 2:153-63. doi: 10.1016/j.cmet.2005.08.004

38. Lee JH, Song MY, Song EK, Kim EK, Moon WS, Han MK, et al. Overexpression of SIRT1 protects pancreatic beta-cells against cytokine toxicity by suppressing the nuclear factor-kappaB signaling pathway. Diabetes (2009) 58:344-51. doi: 10.2337/db07-1795

39. Nemoto S, Fergusson MM, Finkel T. Nutrient availability regulates SIRT1 through a forkhead-dependent pathway. Science (2004) 306:2105-8. doi: 10.1126/science.1101731

40. Bai P, Canto C, Brunyanszki A, Huber A, Szanto M, Cen Y, et al. PARP-2 regulates SIRT1 expression and whole-body energy expenditure. Cell Metab. (2011) 13:450-460. doi: 10.1016/j.cmet.2011.03.013

41. Han L, Zhou R, Niu J, McNutt MA, Wang P, Tong T. SIRT1 is regulated by a PPAR \{gamma\}-SIRT1 negative feedback loop associated with senescence. Nucleic Acids Res. (2010) 38:7458-71. doi: 10.1093/nar/gkq609

42. Hayashida S, Arimoto A, Kuramoto Y, Kozako T, Honda S, Shimeno H, et al. Fasting promotes the expression of SIRT1, an NAD+ -dependent protein deacetylase, via activation of PPARalpha in mice. Mol Cell Biochem. (2010) 339:285-92. doi: 10.1007/s11010-010-0391-Z

43. Okazaki M, Iwasaki Y, Nishiyama M, Taguchi T, Tsugita M, Nakayama S, et al. PPAR $\beta / \delta$ regulates the human SIRT1 gene transcription via Sp1. Endocr J. (2010) 57:403-13. doi: 10.1507/endocrj.K10E-004

44. Yamakuchi M, Ferlito M, Lowenstein CJ. miR-34a repression of SIRT1 regulates apoptosis. Proc Natl Acad Sci USA. (2008) 105:13421-6. doi: 10.1073/pnas.0801613105

45. Rane S, He M, Sayed D, Vashistha H, Malhotra A, Sadoshima J, et al. Downregulation of miR-199a derepresses hypoxia-inducible factor-1alpha and Sirtuin 1 and recapitulates hypoxia preconditioning in cardiac myocytes. Circ Res. (2009) 104:879-86. doi: 10.1161/CIRCRESAHA.108.193102

46. Sasaki T, Maier B, Koclega KD, Chruszcz M, Gluba W, Stukenberg PT, et al. Phosphorylation regulates SIRT1 function. PLoS ONE (2008) 3:e4020. doi: 10.1371/journal.pone.0004020

47. Conrad E, Polonio-Vallon T, Meister M, Matt S, Bitomsky N, Herbel C, et al. HIPK2 restricts SIRT1 activity upon severe DNA damage by a phosphorylation-controlled mechanism. Cell Death Differ. (2016) 23:110-22. doi: $10.1038 / \mathrm{cdd} .2015 .75$

48. Gomes P, Fleming Outeiro T, Cavadas C. Emerging role of sirtuin 2 in the regulation of mammalian metabolism. Trends Pharmacol Sci. (2015) 36:756-68. doi: 10.1016/j.tips.2015.08.001

49. Lemos V, de Oliveira RM, Naia L, Szego E, Ramos E, Pinho S, et al. The NAD+-dependent deacetylase SIRT2 attenuates oxidative stress and mitochondrial dysfunction and improves insulin sensitivity in hepatocytes. Hum Mol Genet. (2017) 26:4105-17. doi: 10.1093/hmg/ddx298

50. Liu T, Yang W, Pang S, Yu S, Yan B. Functional genetic variants within the SIRT2 gene promoter in type 2 diabetes mellitus. Diabetes Res Clin Pract. (2018) 137:200-07. doi: 10.1016/j.diabres.2018.01.012

51. Wang F, Nguyen M, Qin FX, Tong Q. SIRT2 deacetylates FOXO3a in response to oxidative stress and caloric restriction. Aging Cell (2007) 6:505-14. doi: 10.1111/j.1474-9726.2007.00304.x

52. Jing E, Gesta S, Kahn CR. SIRT2 regulates adipocyte differentiation through FoxO1 acetylation/deacetylation. Cell Metab. (2007) 6:105-14. doi: 10.1016/j.cmet.2007.07.003

53. Wang F, Tong Q. SIRT2 suppresses adipocyte differentiation by deacetylating FOXO1 and enhancing FOXO1's repressive interaction with PPARgamma. Mol Biol Cell (2009) 20:801-8. doi: 10.1091/mbc.E08-06-0647

54. Motta MC, Divecha N, Lemieux M, Kamel C, Chen D, Gu W, et al. Mammalian SIRT1 represses forkhead transcription factors. Cell (2004) 116:551-63. doi: 10.1016/S0092-8674(04)00126-6

55. Chen J, Chan AW, To KF, Chen W, Zhang Z, Ren J, et al. SIRT2 overexpression in hepatocellular carcinoma mediates epithelial to mesenchymal transition by protein kinase B/glycogen synthase kinase-3beta/beta-catenin signaling. Hepatology (2013) 57:2287-98. doi: $10.1002 /$ hep. 26278

56. Ramakrishnan G, Davaakhuu G, Kaplun L, Chung WC, Rana A, Atfi A, et al. Sirt2 deacetylase is a novel AKT binding partner critical for AKT activation by insulin. J Biol Chem. (2014) 289:6054-66. doi: 10.1074/jbc.M113.537266
57. Bogan JS, Hendon N, McKee AE, Tsao TS, Lodish HF. Functional cloning of TUG as a regulator of GLUT4 glucose transporter trafficking. Nature (2003) 425:727-33. doi: 10.1038/nature01989

58. Belman JP, Bian RR, Habtemichael EN, Li DT, Jurczak MJ, Alcazar-Roman A, et al. Acetylation of TUG protein promotes the accumulation of GLUT4 glucose transporters in an insulin-responsive intracellular compartment. J Biol Chem. (2015) 290:4447-63. doi: 10.1074/jbc.M114.603977

59. Hutton JC, Sener A, Malaisse WJ. Interaction of branched chain amino acids and keto acids upon pancreatic islet metabolism and insulin secretion. J Biol Chem. (1980) 255:7340-6.

60. Huynh FK, Hu X, Lin Z, Johnson JD, Hirschey MD. Loss of sirtuin 4 leads to elevated glucose- and leucine-stimulated insulin levels and accelerated ageinduced insulin resistance in multiple murine genetic backgrounds. J Inherit Metab Dis. (2018) 41:59-72. doi: 10.1007/s10545-017-0069-8

61. Ahuja N, Schwer B, Carobbio S, Waltregny D, North BJ, Castronovo $\mathrm{V}$, et al. Regulation of insulin secretion by SIRT4, a mitochondrial ADP-ribosyltransferase. J Biol Chem. (2007) 282:33583-92. doi: 10.1074/jbc.M705488200

62. Li SZheng W. Mammalian sirtuins SIRT4 and SIRT7. Prog Mol Biol Transl Sci. (2018) 154:147-68. doi: 10.1016/bs.pmbts.2017.11.001

63. Qin K, Zhang N, Zhang Z, Nipper M, Zhu Z, Leighton J, et al. SIRT6mediated transcriptional suppression of Txnip is critical for pancreatic beta cell function and survival in mice. Diabetologia (2018) 61:906-18. doi: 10.1007/s00125-017-4542-6

64. Kanfi Y, Peshti V, Gil R, Naiman S, Nahum L, Levin E, et al. SIRT6 protects against pathological damage caused by diet-induced obesity. Aging Cell (2010) 9:162-73. doi: 10.1111/j.1474-9726.2009.00544.x

65. Xiao C, Kim HS, Lahusen T, Wang RH, Xu X, Gavrilova O, et al. SIRT6 deficiency results in severe hypoglycemia by enhancing both basal and insulin-stimulated glucose uptake in mice. J Biol Chem. (2010) 285:36776-84. doi: $10.1074 /$ jbc.M110.168039

66. Song MY, Wang J, Ka SO, Bae EJ, Park BH. Insulin secretion impairment in Sirt6 knockout pancreatic beta cells is mediated by suppression of the FoxO1-Pdx1-Glut2 pathway. Sci Rep. (2016) 6:30321. doi: 10.1038/srep30321

67. Xiong X, Sun X, Wang Q, Qian X, Zhang Y, Pan X, et al. SIRT6 protects against palmitate-induced pancreatic beta-cell dysfunction and apoptosis. J Endocrinol. (2016) 231:159-65. doi: 10.1530/JOE-16-0317

68. Bouche C, Serdy S, Kahn CR, Goldfine AB. The cellular fate of glucose and its relevance in type 2 diabetes. Endocr Rev. (2004) 25:807-30. doi: 10.1210/er.2003-0026

69. Koo SH, Flechner L, Qi L, Zhang X, Screaton RA, Jeffries S, et al. The CREB coactivator TORC2 is a key regulator of fasting glucose metabolism. Nature (2005) 437:1109-11. doi: 10.1038/nature03967

70. Puigserver P, Rhee J, Donovan J, Walkey CJ, Yoon JC, Oriente F, et al. Insulinregulated hepatic gluconeogenesis through FOXO1-PGC-1alpha interaction. Nature (2003) 423:550-5. doi: 10.1038/nature01667

71. Rodgers JT, Lerin C, Haas W, Gygi SP, Spiegelman BM, Puigserver P. Nutrient control of glucose homeostasis through a complex of PGC-1alpha and SIRT1. Nature (2005) 434:113-8. doi: 10.1038/nature03354

72. Lerin C, Rodgers JT, Kalume DE, Kim SH, Pandey A, Puigserver P. GCN5 acetyltransferase complex controls glucose metabolism through transcriptional repression of PGC-1alpha. Cell Metab. (2006) 3:429-38. doi: 10.1016/j.cmet.2006.04.013

73. Jiang W, Wang S, Xiao M, Lin Y, Zhou L, Lei Q, et al. Acetylation regulates gluconeogenesis by promoting PEPCK1 degradation via recruiting the UBR5 ubiquitin ligase. Mol Cell (2011) 43:33-44. doi: 10.1016/j.molcel.2011.04.028

74. Watanabe $\mathrm{H}$, Inaba $\mathrm{Y}$, Kimura K, Matsumoto M, Kaneko S, Kasuga $M$, et al. Sirt2 facilitates hepatic glucose uptake by deacetylating glucokinase regulatory protein. Nat Commun. (2018) 9:30. doi: 10.1038/s41467-017-02537-6

75. Kumar S, Lombard DB. Generation and purification of catalytically active recombinant sirtuin5 (SIRT5) protein. Methods Mol Biol. (2016) 1436:241-57. doi: 10.1007/978-1-4939-3667-0_16

76. Zhang P, Tu B, Wang H, Cao Z, Tang M, Zhang C, et al. Tumor suppressor p53 cooperates with SIRT6 to regulate gluconeogenesis by promoting FoxO1 nuclear exclusion. Proc Natl Acad Sci USA. (2014) 111:10684-9. doi: $10.1073 /$ pnas. 1411026111 
77. Dominy JE Jr, Lee Y, Jedrychowski MP, Chim H, Jurczak MJ, Camporez JP, et al. The deacetylase Sirt6 activates the acetyltransferase GCN5 and suppresses hepatic gluconeogenesis. Mol Cell (2012) 48:900-13. doi: 10.1016/j.molcel.2012.09.030

78. Schwer B, Schumacher B, Lombard DB, Xiao C, Kurtev MV, Gao J, et al. Neural sirtuin 6 (Sirt6) ablation attenuates somatic growth and causes obesity. Proc Natl Acad Sci USA. (2010) 107:21790-4. doi: 10.1073/pnas.1016306107

79. Boily G, Seifert EL, Bevilacqua L, He XH, Sabourin G, Estey C, et al. SirT1 regulates energy metabolism and response to caloric restriction in mice. PLoS ONE (2008) 3:e1759. doi: 10.1371/journal.pone.0001759

80. Chen D, Steele AD, Lindquist S, Guarente L. Increase in activity during calorie restriction requires Sirt1. Science (2005) 310:1641. doi: 10.1126/science. 1118357

81. Hebert AS, Dittenhafer-Reed KE, Yu W, Bailey DJ, Selen ES, Boersma $\mathrm{MD}$, et al. Calorie restriction and SIRT3 trigger global reprogramming of the mitochondrial protein acetylome. Mol Cell (2013) 49:186-99. doi: 10.1016/j.molcel.2012.10.024

82. Qiu X, Brown K, Hirschey MD, Verdin E, Chen D. Calorie restriction reduces oxidative stress by SIRT3-mediated SOD2 activation. Cell Metab. (2010) 12:662-7. doi: 10.1016/j.cmet.2010.11.015

83. Someya S, Yu W, Hallows WC, Xu J, Vann JM, Leeuwenburgh C, et al. Sirt3 mediates reduction of oxidative damage and prevention of agerelated hearing loss under caloric restriction. Cell (2010) 143:802-12. doi: 10.1016/j.cell.2010.10.002

84. Liu Y, Dentin R, Chen D, Hedrick S, Ravnskjaer K, Schenk S, et al. A fasting inducible switch modulates gluconeogenesis via activator/coactivator exchange. Nature (2008) 456:269-73. doi: 10.1038/nature07349

85. Milne JC, Lambert PD, Schenk S, Carney DP, Smith JJ, Gagne DJ, et al. Small molecule activators of SIRT1 as therapeutics for the treatment of type 2 diabetes. Nature (2007) 450:712-6. doi: 10.1038/nature06261

86. Barger JL, Kayo T, Vann JM, Arias EB, Wang J, Hacker TA, et al. A low dose of dietary resveratrol partially mimics caloric restriction and retards aging parameters in mice. PLoS ONE (2008) 3:e2264. doi: 10.1371/journal.pone.0002264

87. Kanfi Y, Naiman S, Amir G, Peshti V, Zinman G, Nahum L, et al. The sirtuin SIRT6 regulates lifespan in male mice. Nature (2012) 483:218-21. doi: 10.1038/nature10815

88. Satoh A, Brace CS, Ben-Josef G, West T, Wozniak DF, Holtzman DM, et al. SIRT1 promotes the central adaptive response to diet restriction through activation of the dorsomedial and lateral nuclei of the hypothalamus. J Neurosci. (2010) 30:10220-32. doi: 10.1523/JNEUROSCI.1385-10.2010

89. Zhang HJ, Zhang XF, Ma ZM, Pan LL, Chen Z, Han HW, et al. Irisin is inversely associated with intrahepatic triglyceride contents in obese adults. J Hepatol. (2013) 59:557-62. doi: 10.1016/j.jhep.2013.04.030

90. de Moura MB, Uppala R, Zhang Y, Van Houten B, Goetzman ES. Overexpression of mitochondrial sirtuins alters glycolysis and mitochondrial function in HEK293 cells. PLoS ONE (2014) 9:e106028. doi: 10.1371/journal.pone.0106028

91. Gerhart-Hines Z, Rodgers JT, Bare O, Lerin C, Kim SH, Mostoslavsky $\mathrm{R}$, et al. Metabolic control of muscle mitochondrial function and fatty acid oxidation through SIRT1/PGC-1alpha. EMBO J. (2007) 26:1913-23. doi: 10.1038/sj.emboj.7601633

92. Giralt A, Hondares E, Villena JA, Ribas F, Diaz-Delfin J, Giralt M, et al. Peroxisome proliferator-activated receptor-gamma coactivator-1alpha controls transcription of the Sirt3 gene, an essential component of the thermogenic brown adipocyte phenotype. J Biol Chem. (2011) 286:16958-66. doi: 10.1074/jbc.M110.202390

93. Kong X, Wang R, Xue Y, Liu X, Zhang H, Chen Y, et al. Sirtuin 3, a new target of PGC-1alpha, plays an important role in the suppression of ROS and mitochondrial biogenesis. PLoS ONE (2010) 5:e11707. doi: 10.1371/journal.pone.0011707

94. Shi T, Wang F, Stieren E, Tong Q. SIRT3, a mitochondrial sirtuin deacetylase, regulates mitochondrial function and thermogenesis in brown adipocytes. J Biol Chem. (2005) 280:13560-7. doi: 10.1074/jbc.M414670200

95. Hirschey MD, Shimazu T, Goetzman E, Jing E, Schwer B, Lombard DB, et al. SIRT3 regulates mitochondrial fatty-acid oxidation by reversible enzyme deacetylation. Nature (2010) 464:121-5. doi: 10.1038/nature08778
96. Ho L, Titus AS, Banerjee KK, George S, Lin W, Deota S, et al. SIRT4 regulates ATP homeostasis and mediates a retrograde signaling via AMPK. Aging (2013) 5:835-49. doi: 10.18632/aging.100616

97. Zhou L, Wang F, Sun R, Chen X, Zhang M, Xu Q, et al. SIRT5 promotes IDH2 desuccinylation and G6PD deglutarylation to enhance cellular antioxidant defense. EMBO Rep. (2016) 17:811-22. doi: 10.15252/embr.201541643

98. Zhong L, D'Urso A, Toiber D, Sebastian C, Henry RE, Vadysirisack DD, et al. The histone deacetylase Sirt6 regulates glucose homeostasis via Hiflalpha. Cell (2010) 140:280-93. doi: 10.1016/j.cell.2009.12.041

99. Hu CJ, Iyer S, Sataur A, Covello KL, Chodosh LA, Simon MC. Differential regulation of the transcriptional activities of hypoxia-inducible factor 1 alpha (HIF-1 $\alpha$ ) and HIF-2 $\alpha$ in stem cells. Mol Cell Biol. (2006) 26:3514-26. doi: 10.1128/MCB.26.9.3514-3526.2006

100. Randle PJ, Garland PB, Hales CN, Newsholme EA. The glucose fatty-acid cycle. Its role in insulin sensitivity and the metabolic disturbances of diabetes mellitus. Lancet (1963) 1:785-9.

101. Furler SM, Poynten AM, Kriketos AD, Lowy AJ, Ellis BA, Maclean EL, et al. Independent influences of central fat and skeletal muscle lipids on insulin sensitivity. Obes Res. (2001) 9:535-43. doi: 10.1038/oby.2001.70

102. Feige JN, Lagouge M, Canto C, Strehle A, Houten SM, Milne JC, et al. Specific SIRT1 activation mimics low energy levels and protects against diet-induced metabolic disorders by enhancing fat oxidation. Cell Metab. (2008) 8:347-58. doi: 10.1016/j.cmet.2008.08.017

103. Iwabu M, Yamauchi T, Okada-Iwabu M, Sato K, Nakagawa T, Funata M, et al. Adiponectin and AdipoR1 regulate PGC- $1 \alpha$ and mitochondria by $\mathrm{Ca}(2+)$ and AMPK/SIRT1. Nature (2010) 464:1313-9. doi: 10.1038/nature08991

104. Arora A, Dey CS. SIRT2 negatively regulates insulin resistance in C2C12 skeletal muscle cells. Biochim Biophys Acta (2014) 1842:1372-8. doi: 10.1016/j.bbadis.2014.04.027

105. Jing E, Emanuelli B, Hirschey MD, Boucher J, Lee KY, Lombard D, et al. Sirtuin-3 (Sirt3) regulates skeletal muscle metabolism and insulin signaling via altered mitochondrial oxidation and reactive oxygen species production. Proc Natl Acad Sci USA. (2011) 108:14608-13. doi: 10.1073/pnas.1111308108

106. Jing E, O’Neill BT, Rardin MJ, Kleinridders A, Ilkeyeva OR, Ussar S, et al. Sirt3 regulates metabolic flexibility of skeletal muscle through reversible enzymatic deacetylation. Diabetes (2013) 62:3404-17. doi: $10.2337 / \mathrm{db} 12-1650$

107. Muoio DM, Neufer PD. Lipid-induced mitochondrial stress and insulin action in muscle. Cell Metab. (2012) 15:595-605. doi: 10.1016/j.cmet.2012.04.010

108. Lantier L, Williams AS, Williams IM, Yang KK, Bracy DP, Goelzer M, et al. SIRT3 is crucial for maintaining skeletal muscle insulin action and protects against severe insulin resistance in high-fat-fed mice. Diabetes (2015) 64:3081-92. doi: 10.2337/db14-1810

109. Nasrin N, Wu X, Fortier E, Feng Y, Bare OC, Chen S, et al. SIRT4 regulates fatty acid oxidation and mitochondrial gene expression in liver and muscle cells. J Biol Chem. (2010) 285:31995-2002. doi: 10.1074/jbc.M110.124164

110. Kelley DE, Goodpaster B, Wing RR, Simoneau JA. Skeletal muscle fatty acid metabolism in association with insulin resistance, obesity, and weight loss. Am J Physiol. (1999) 277:E1130-41.

111. Kelley DE, He J, Menshikova EV, Ritov VB. Dysfunction of mitochondria in human skeletal muscle in type 2 diabetes. Diabetes (2002) 51:2944-50. doi: 10.2337/diabetes.51.10.2944

112. Rodgers JT, Puigserver P. Fasting-dependent glucose and lipid metabolic response through hepatic sirtuin 1. Proc Natl Acad Sci USA. (2007) 104:12861-6. doi: 10.1073/pnas.0702509104

113. Purushotham A, Schug TT, Xu Q, Surapureddi S, Guo X, Li X. Hepatocyte-specific deletion of SIRT1 alters fatty acid metabolism and results in hepatic steatosis and inflammation. Cell Metab. (2009) 9:327-38. doi: 10.1016/j.cmet.2009.02.006

114. Sugden MC, Caton PW, Holness MJ. PPAR control: it's SIRTainly as easy as PGC. J Endocrinol. (2010) 204:93-104. doi: 10.1677/JOE-09-0359

115. Ponugoti B, Kim DH, Xiao Z, Smith Z, Miao J, Zang M, et al. SIRT1 deacetylates and inhibits SREBP-1C activity in regulation of hepatic lipid metabolism. J Biol Chem. (2010) 285:33959-70. doi: 10.1074/jbc.M110.122978

116. Krishnan J, Danzer C, Simka T, Ukropec J, Walter KM, Kumpf S, et al. Dietary obesity-associated Hiflalpha activation in adipocytes restricts fatty 
acid oxidation and energy expenditure via suppression of the Sirt2-NAD+ system. Genes Dev. (2012) 26:259-70. doi: 10.1101/gad.180406.111

117. Lombard DB, Alt FW, Cheng HL, Bunkenborg J, Streeper RS, Mostoslavsky R, et al. Mammalian Sir2 homolog SIRT3 regulates global mitochondrial lysine acetylation. Mol Cell Biol. (2007) 27:8807-14. doi: 10.1128/MCB.01636-07

118. Hallows WC, Yu W, Smith BC, Devries MK, Ellinger JJ, Someya S, et al. Sirt3 promotes the urea cycle and fatty acid oxidation during dietary restriction. Mol Cell (2011) 41:139-49. doi: 10.1016/j.molcel.2011.01.002

119. Shimazu T, Hirschey MD, Hua L, Dittenhafer-Reed KE, Schwer B, Lombard $\mathrm{DB}$, et al. SIRT3 deacetylates mitochondrial 3-hydroxy-3-methylglutaryl CoA synthase 2 and regulates ketone body production. Cell Metab. (2010) 12:654-61. doi: 10.1016/j.cmet.2010.11.003

120. Hirschey MD, Shimazu T, Jing E, Grueter CA, Collins AM, Aouizerat B, et al. SIRT3 deficiency and mitochondrial protein hyperacetylation accelerate the development of the metabolic syndrome. Mol Cell (2011) 44:177-90. doi: 10.1016/j.molcel.2011.07.019

121. Yoshizawa T, Karim MF, Sato Y, Senokuchi T, Miyata K, Fukuda $\mathrm{T}$, et al. SIRT7 controls hepatic lipid metabolism by regulating the ubiquitin-proteasome pathway. Cell Metab. (2014) 19:712-21. doi: 10.1016/j.cmet.2014.03.006

122. Karim MF, Yoshizawa T, Sobuz SU, Sato Y, Yamagata K. Sirtuin 7dependent deacetylation of DDB1 regulates the expression of nuclear receptor TR4. Biochem Biophys Res Commun. (2017) 490:423-428. doi: 10.1016/j.bbrc.2017.06.057

123. Ryu D, Jo YS, Lo Sasso G, Stein S, Zhang H, Perino A, et al. A SIRT7-dependent acetylation switch of GABPbetal controls mitochondrial function. Cell Metab. (2014) 20:856-69. doi: 10.1016/j.cmet.2014.08.001

124. Shin J, He M, Liu Y, Paredes S, Villanova L, Brown K, et al. SIRT7 represses Myc activity to suppress ER stress and prevent fatty liver disease. Cell Rep. (2013) 5:654-65. doi: 10.1016/j.celrep.2013.10.007

125. Laurent G, de Boer VC, Finley LW, Sweeney M, Lu H, Schug TT, et al. SIRT4 represses peroxisome proliferator-activated receptor alpha activity to suppress hepatic fat oxidation. Mol Cell Biol. (2013) 33:4552-61. doi: 10.1128/MCB.00087-13

126. Rajala MW, Scherer PE. Minireview: the adipocyte-at the crossroads of energy homeostasis, inflammation, and atherosclerosis. Endocrinology (2003) 144:3765-73. doi: 10.1210/en.2003-0580

127. Berg AH, Scherer PE. Adipose tissue, inflammation, and cardiovascular disease. Circ Res. (2005) 96:939-49. doi: 10.1161/01.RES.0000163635.62927.34

128. Kadowaki T, Yamauchi T. Adiponectin and adiponectin receptors. Endocr Rev. (2005) 26:439-51. doi: 10.1210/er.2005-0005

129. Picard F, Kurtev M, Chung N, Topark-Ngarm A, Senawong T, Machado De Oliveira R, et al. Sirtl promotes fat mobilization in white adipocytes by repressing PPAR-gamma. Nature (2004) 429:771-6. doi: 10.1038 /nature 02583

130. Qiang L, Wang L, Kon N, Zhao W, Lee S, Zhang Y, et al. Brown remodeling of white adipose tissue by SirT1-dependent deacetylation of Ppargamma. Cell (2012) 150:620-32. doi: 10.1016/j.cell.2012.06.027

131. Kurylowicz A, Owczarz M, Polosak J, Jonas MI, Lisik W, Jonas M, et al. SIRT1 and SIRT7 expression in adipose tissues of obese and normal-weight individuals is regulated by microRNAs but not by methylation status. Int $J$ Obes. (2016) 40:1635-42. doi: 10.1038/ijo.2016.131

132. Cioffi M, Vallespinos-Serrano M, Trabulo SM, Fernandez-Marcos PJ, Firment AN, Vazquez BN, et al. MiR-93 controls adiposity via inhibition of Sirt7 and Tbx3. Cell Rep. (2015) 12:1594-605. doi: 10.1016/j.celrep.2015.08.006

133. Tong Z, Wang Y, Zhang X, Kim DD, Sadhukhan S, Hao Q, et al. SIRT7 Is activated by DNA and deacetylates histone $\mathrm{H} 3$ in the chromatin context. ACS Chem Biol. (2016) 11:742-7. doi: 10.1021/acschembio.5b01084

134. Tong Z, Wang M, Wang Y, Kim DD, Grenier JK, Cao J, et al. SIRT7 is an RNA-activated protein lysine deacylase. ACS Chem Biol. (2017) 12:300-10. doi: 10.1021/acschembio.6b00954

135. Kuang J, Zhang Y, Liu Q, Shen J, Pu S, Cheng S, et al. Fatspecific Sirt6 ablation sensitizes mice to high-fat diet-induced obesity and insulin resistance by inhibiting lipolysis. Diabetes (2017) 66:1159-71. doi: $10.2337 / \mathrm{db} 16-1225$
136. Ramadori G, Fujikawa T, Fukuda M, Anderson J, Morgan DA, Mostoslavsky $\mathrm{R}$, et al. SIRT1 deacetylase in POMC neurons is required for homeostatic defenses against diet-induced obesity. Cell Metab. (2010) 12:78-87. doi: 10.1016/j.cmet.2010.05.010

137. Ramadori G, Fujikawa T, Anderson J, Berglund ED, Frazao R, Michan S, et al. SIRT1 deacetylase in SF1 neurons protects against metabolic imbalance. Cell Metab. (2011) 14:301-12. doi: 10.1016/j.cmet.2011.06.014

138. Sasaki T, Kim HJ, Kobayashi M, Kitamura YI, Yokota-Hashimoto H, Shiuchi $\mathrm{T}$, et al. Induction of hypothalamic Sirt1 leads to cessation of feeding via agouti-related peptide. Endocrinology (2010) 151:2556-66. doi: 10.1210/en.2009-1319

139. Velasquez DA, Martinez G, Romero A, Vazquez MJ, Boit KD, Dopeso-Reyes IG, et al. The central Sirtuin 1/p53 pathway is essential for the orexigenic action of ghrelin. Diabetes (2011) 60:1177-85. doi: 10.2337/db10-0802

140. Lu M, Sarruf DA, Li P, Osborn O, Sanchez-Alavez M, Talukdar $S$, et al. Neuronal Sirt1 deficiency increases insulin sensitivity in both brain and peripheral tissues. J Biol Chem. (2013) 288:10722-35. doi: $10.1074 /$ jbc.M112.443606

141. Roy Chowdhury S, Djordjevic J, Thomson E, Smith DR, Albensi BC, Fernyhough P. Depressed mitochondrial function and electron transport complex II-mediated $\mathrm{H} 2 \mathrm{O} 2$ production in the cortex of type 1 diabetic rodents. Mol Cell Neurosci. (2018) 90:49-59. doi: 10.1016/j.mcn.2018.05.006

142. Dong Y, Guo T, Traurig M, Mason CC, Kobes S, Perez J, et al. SIRT1 is associated with a decrease in acute insulin secretion and a sex specific increase in risk for type 2 diabetes in Pima Indians. Mol Genet Metab. (2011) 104:661-5. doi: 10.1016/j.ymgme.2011.08.001

143. Maeda S, Koya D, Araki SI, Babazono T, Umezono T, Toyoda M, et al. Association between single nucleotide polymorphisms within genes encoding sirtuin families and diabetic nephropathy in Japanese subjects with type 2 diabetes. Clin Exp Nephrol. (2011) 15:381-90. doi: 10.1007/s10157-011-0418-0

144. Botden IP, Zillikens MC, de Rooij SR, Langendonk JG, Danser AH, Sijbrands EJ, et al. Variants in the SIRT1 gene may affect diabetes risk in interaction with prenatal exposure to famine. Diabetes Care (2012) 35:424-6. doi: $10.2337 / \mathrm{dc} 11-1203$

145. Sosnowska B, Mazidi M, Penson P, Gluba-Brzozka A, Rysz J, Banach M. The sirtuin family members SIRT1, SIRT3 and SIRT6: their role in vascular biology and atherogenesis. Atherosclerosis (2017) 265:275-82. doi: 10.1016/j.atherosclerosis.2017.08.027

146. Tan MH, Alquraini H, Mizokami-Stout K, MacEachern M. Metformin: from research to clinical practice. Endocrinol Metab Clin North Am. (2016) 45:819-43. doi: 10.1016/j.ecl.2016.06.008

147. Sliwinska A, Drzewoski J. Molecular action of metformin in hepatocytes: an updated insight. Curr Diabetes Rev. (2015) 11:175-81. doi: 10.2174/1573399811666150325233108

148. Knowler WC, Barrett-Connor E, Fowler SE, Hamman RF, Lachin JM, Walker EA, et al. Reduction in the incidence of type 2 diabetes with lifestyle intervention or metformin. N Engl J Med. (2002) 346:393-403. doi: 10.1056/NEJMoa012512

149. Moin T, Schmittdiel JA, Flory JH, Yeh J, Karter AJ, Kruge LE, et al. Review of metformin use for type 2 diabetes prevention. Am J Prev Med. (2018) 55:565-74. doi: 10.1016/j.amepre.2018.04.038

150. Kaleida Health. Effect of Resveratrol on Insulin Resistance and Inflammatory Mediators in Obese and Type 2 Diabetic Subjects, 2010. ClinicalTrials.gov. Identifier: NCT01158417 Available online at: http://clinicaltrials.gov/ct2/ show/NCT01158417?term $=$ NCT01158417.\&rank $\$=\$ 1$

151. Mellini P, Valente S, Mai A. Sirtuin modulators: an updated patent review (2012-2014). Expert Opin Ther Pat. (2015) 25:5-15. doi: $10.1517 / 13543776.2014 .982532$

152. Boocock DJ, Faust GE, Patel KR, Schinas AM, Brown VA, Ducharme MP, et al. Phase I dose escalation pharmacokinetic study in healthy volunteers of resveratrol, a potential cancer chemopreventive agent. Cancer Epidemiol Biomarkers Prev. (2007) 16:1246-52. doi: 10.1158/1055-9965.EPI-07-0022

153. GlaxoSmithKline. A Clinical Study to Assess the Safety, Tolerability, and Activity of Oral SRT2104 Capsules Administered for 28 Days to Subjects With Type 2 Diabetes Mellitus. 2011. ClinicalTrials.gov. Identifier: NCT01018017 Available online at: http://clinicaltrials.gov/ct2/show/study/NCT01018017? term $=$ NCT01018017.\&rank $=1$ 
154. GlaxoSmithKline. A Phase I Randomized, Placebo-Controlled, Single-Blind, Multiple-Dose, Dose-Escalation Clinical Study to Assess the Safety and Pharmacokinetics of SRT2379 in Normal Healthy Male Volunteers, 2011. ClinicalTrials.gov.Identifier: NCT01018628 Available online at: http:// clinicaltrials.gov/ct2/show/NCT01018628?term $=$ NCT01018628\&rank $=1$

155. Rardin MJ, He W, Nishida Y, Newman JC, Carrico C, Danielson $\mathrm{SR}$, et al. SIRT5 regulates the mitochondrial lysine succinylome and metabolic networks. Cell Metab. (2013) 18:920-33. doi: 10.1016/j.cmet.2013. 11.013

156. Cohen HY, Miller C, Bitterman KJ, Wall NR, Hekking B, Kessler B, et al. Calorie restriction promotes mammalian cell survival by inducing the SIRT1 deacetylase. Science (2004) 305:390-2. doi: 10.1126/science.10 99196

157. Mathias RA, Greco TM, Oberstein A, Budayeva HG, Chakrabarti R, Rowland EA, et al. Sirtuin 4 is a lipoamidase regulating pyruvate dehydrogenase complex activity. Cell (2014) 159:1615-25. doi: 10.1016/j.cell.2014. 11.046

158. Park J, Chen Y, Tishkoff DX, Peng C, Tan M, Dai L, et al. SIRT5-mediated lysine desuccinylation impacts diverse metabolic pathways. Mol Cell (2013) 50:919-30. doi: 10.1016/j.molcel.2013. 06.001
159. Burns J, Yokota T, Ashihara H, Lean ME, Crozier A. Plant foods and herbal sources of resveratrol. J Agric Food Chem. (2002) 50:3337-40. doi: $10.1021 /$ jf0112973

160. Hung CH, Chan SH, Chu PM, Tsai KL. Quercetin is a potent anti-atherosclerotic compound by activation of SIRT1 signaling under oxLDL stimulation. Mol Nutr Food Res. (2015) 59:1905-17. doi: 10.1002/mnfr.201500144

161. Affuso F, Mercurio V, Fazio V, Fazio S. Cardiovascular and metabolic effects of Berberine. World J Cardiol. (2010) 2:71-7. doi: 10.4330/wjc.v2.i4.71

Conflict of Interest Statement: The authors declare that the research was conducted in the absence of any commercial or financial relationships that could be construed as a potential conflict of interest.

Copyright $\odot 2018$ Song, Yang, Jia, Li, Tan, Ma, Shi and Feng. This is an open-access article distributed under the terms of the Creative Commons Attribution License (CC $B Y)$. The use, distribution or reproduction in other forums is permitted, provided the original author(s) and the copyright owner(s) are credited and that the original publication in this journal is cited, in accordance with accepted academic practice. No use, distribution or reproduction is permitted which does not comply with these terms. 